\title{
THE 'SOCIALIZATION' OF MARITIME GLOBAL GOVERNANCE AND TAIWAN: PERCEIVING THE BENEFITS *
}

\author{
Leonard Hammer
}

\begin{abstract}
Certain maritime global governance frameworks exist and can at times even be effective. Yet, serious implementation matters and dire environmental circumstances persist. Control mechanisms are mainly in the hands of states or outmoded international organizations facing off against powerful economic intermediaries engaged in exploitation and driven by strong demand from export markets. Political interests also weaken the system, such as disallowing important maritime actors like Taiwan from taking a part in the process. Given that maritime global governance is constantly shifting due to a host of changing processes, proper governance requires structural alteration as well as temporal accountability.

A socialization context for maritime global governance, that emphasizes partnership models incorporating both private and public actors (such as market-based bodies with civil society actors to inform and direct regulatory bodies), can not only improve maritime governance but also allow for participation by Taiwan. Including a wider range of stakeholders like media, politicians, interest groups, and consumers along with an assistive reference to new forms of technologies, can result in activating infrastructures that combine varying interests (like economic and environment) and result in a more effective form of maritime global governance. At the same time, it can open the door for Taiwan to effectively join in environmental initiatives and international projects relating to maritime governance.
\end{abstract}

Keywords: maritime global governance, socialization, Taiwan, global process, global policy.

\section{Introduction}

Socialization can prove to be an effective concept in today's framework of states, especially when striving for a form of viable and applicable global governance. States are composed of diverse interests, disparate power groups and multifaceted populations armed with a slew of information and capacities ranging from human rights initiatives, ability to directly challenge the state, social protest or fomenting unrest using the broadform reach of social media, or appealing to an international organization or agency to counterbalance the state and its power apparatus (see generally Risse, Ropp, and Sikkink 1999). The importance of socialization is the manner by which it creates operative avenues for inculcating human rights norms or environmental principles into the domestic system of a state, be it through laws, discourse, argumentation, or other forms of sustained political or social interactions that create adaptive behavior (Ecclestone 2013: 
46). These include adaptation of norms and utilizing them within strategic bargaining as a means of enhancing protection, raising moral consciousness (especially through argumentation and persuasion), and institutionalizing norms within international organizations and the state as grounds for further acculturation and habitualization of principles that become embedded and serve as central components of policy development and analysis (see e.g., Shahid and Yerbury 2014; Greenhill 2010).

Granted, various states might find themselves at different levels of socialization when considering important human rights norms or environmental concerns. Some states might repress human rights activity or deny the existence or validity of norms or environmental concerns, whilst other states might just be at the cusp of conceding to existing rules and acknowledging some form of prescriptive status to important norms (leading eventually to rule consistent behavior). What makes socialization interesting is the process of raising morally conscious issues through available means of argumentation and persuasion that eventually convinces relevant actors, including states, of the veracity and legitimacy of the norms and concepts being espoused and asserted as grounds for appropriate action and sound policy making. Thus, the emerging benefit and capacity of the socialization of norms going towards the protection of human rights or the environment for example stem from many sources. Sources include of course legal codification resulting from international treaties, but also can be realized from the penetration of norms beyond a formal legal context. Norms become embedded within, and part and parcel with, the culture and discursive framework that drives the state, its actors and apparatus, and the people affected by the state where all of the aforementioned will refer, rely, and utilize these norms to create a viable and legitimate framework of operations.

Especially when accounting for the globalization of ideas and the turn by states towards some form of acknowledgment regarding a global governance structure, ${ }^{1}$ it is apparent that the slow creep (or sometimes jump) of the socialization of norms maintains an important and seminal effect in moving global governance further forward to create a viable and even lasting operative framework (Barnett and Finnemore 2004: 161). Indeed, demands of legitimacy are emanating not just from national governments, but also from civil society actors who refer to global governance as providing the grounds for social justice, equity, ecological integrity, and other societal values that can assist to create a viable international order (Bernstein 2011: 18). As private actors infiltrate the realm of formerly public functions (Picciotto 2006: 2-3), and as civil society actors emerge to provide the voice and call for many social justice initiatives, the socialization process that operates within the global governance context takes on greater importance as it re-shapes the contours and meaning of legitimacy among nations (Bernstein 2011: 19). Political authority is increasingly occurring via interactions with a variety of actors beyond the state, to include civil society actors, private companies, and even individuals. Thus, socialization folds into global governance in a rather effective manner. Socialization can provide the grounds for creating a framework of legitimacy given the breadth and scope of the actors involved in the process, and also because socialization grounds the actions of such actors based on what has emerged as being socially accepted (pursuant to norms, behavioral patterns, ongoing discourse, and other forms of agreements or even soft law mechanisms). 
In the realm of maritime global governance, there is a sharp movement away from outmoded state centric models, and a turn towards sustainable development as a context by which to build forms of governance. This is especially apparent when integrating important factors like maritime awareness and environmental concerns (ChintoanUta and Silva 2017: 37; see also discussion infra). Socialization neatly fits into a maritime governance structure driven by sustainable development given the importance and acknowledgment of the manner by which sustainable development norms and values (many of which emanate from the human rights and environmental framework) enter the lexicon of global governance as a means of entrenching such norms and values. ${ }^{2}$ These norms and ideals become a regular part of the discourse and language used and relied upon by the relevant actors involved (including not just states but also NGOs, civil society actors, international organizations, and other actors be they private or public entities). Socialization can serve to move forward realistic and effective maritime global governance structures that reflect seminal concerns and issues, taking into account the real issues facing maritime actors and environmental interests (beyond just political grandstanding by states) rather than be mired in ineffective, traditional, statecentric models.

\section{Maritime Global Governance}

Global maritime governance should be constructed in a manner that is enabled to address seemingly dichotomous themes. Matters like hyper industry competition as opposed to controlling monopolies, government intervention (such as providing subsidies) as opposed to moves for privatization, a strive for greater economic development at all costs as opposed to respect for environmental concerns, and matters of state defense and security versus a desire for maintaining open and navigable seas are converging concerns that tend to emerge at the same time.

Understanding governance as a means to establish processes and structures that steer actors towards desirable outcomes, it is apparent that there exist many reasons for moving towards a form of global maritime governance. The most evident are external concerns regarding the environment and fishing stocks, potential human rights matters involving labor rights in the shipping and fishing industries, important economic acknowledgments that account for notions of development and the resultant economic impacts, and even aspirations towards global governance that adequately capture the opinions and desires of the world, writ large (see, e.g., Selkou and Roe 2004). These varying and diverse interests demand a broad array of involvement by many actors, including the state, international regulatory bodies, and other surrounding actors who have knowledge and insight into the means for effectuating maritime global governance.

Of course, the strive for maritime governance is shaped by forms of overarching structures (be it international, regional, or domestic) that direct, control, and influence maritime matters. The 1982 Convention on the Law of the Sea (LOS) and its attendant bodies (like the LOS Tribunal), for example, can be a central feature in maritime governance. The International Seabed Authority governs issues pertaining to state claims over the 200 nautical mile line (where states may claim up to 350 nautical miles) as well as operates in to regulate High Seas matters. The International Maritime Organization serves to assist with navigation, anti-piracy efforts, and environmental concerns (see, e.g., Karim 2015). Regional bodies are another potential form of maritime govern- 
ance. Many regional and local-oriented forms of maritime governance existed for quite some time to ensure for regulated and sustainable use of resources. ${ }^{3}$

The differing approaches are quite stark for a country like Taiwan, an important actor in maritime activities and a willing participant in the governance thereof, yet subject to forms of isolation due to an ongoing political dispute with Mainland China. ${ }^{4}$ Taiwan is not a member of the Asia Pacific Fishery Commission, for example, because the Commission operates under the Food and Agricultural Organization of the United Nations, ${ }^{5}$ thus excluding Taiwan given the participation by mainland China and its refusal to have Taiwan as a separate or independent member in a UN based organization. Yet, in reality Taiwan is the third in the world (using available figures from 2014) for tuna fishing (after Indonesia and Japan), ${ }^{6}$ quite a feat for a small country. As a result, Taiwan has become a member (usually as Chinese Taipei or the Fishing Entity of Taiwan) in more regional organizations that deal with fishing and conservation, such as the Commission for the Conservation of Southern Bluefin Tuna (CCSBT), ${ }^{7}$ the North Pacific Fisheries Commission (NPFC), ${ }^{8}$ the South Pacific Regional Fisheries Management Organisation (sic) (SPRFMO), ${ }^{9}$ and the Inter-American Tropical Tuna Association (IATTC). ${ }^{10}$ These regional organizations are important as they begin to address issues of over fishing and other illegal activities, with the goal of managing fishing in a sustainable manner. ${ }^{11}$

The need then for a realist approach towards maritime global governance, in a manner that incorporates all relevant actors who impact upon fishing stocks and other environmental concerns, should be of paramount importance when addressing matters of sustainable development and conservation (key desirable outcomes for maritime global governance).

\section{General Problems of Note}

Yet, serious implementation matters and dire environmental circumstances persist that indicate the need for a reoriented form of maritime global governance. Control mechanisms are mainly in the hands of national and local governments (who cannot or sometimes will not act to uphold standards) or international organizations that are based on unrealistic notions of unlimited ocean resources and outmoded concepts of perceiving the oceans as being divided into territorial jurisdictions (Stephens 2015: 778). International organizations and their state members have been ineffective thus far in creating a viable governance policy (see, e.g., Kopela 2016: 89). These organizations are up against extremely powerful economic intermediaries many times engaged in exploitation and largely driven by strong demand from export markets. And all are subject to (and even involved in) corrupt and illegal activities that current rules and norms do not adequately address.

Granted forms of governance emerge when thinking about the LOS. The so-called 'constitution of the oceans', while acknowledging a state's sovereign right to its resources, contains provisions calling on states to protect the marine environment ${ }^{12}$ and only catch species up to their maximum sustainable yield. ${ }^{13}$ Additionally, one can refer to opinions concerning the obligation on flag states to regulate their vessels (an arguably broad interpretation of the LOS Convention) (see, e.g., Schatz 2016: 327) or the 2009 move by the FAO to impose responsibilities on port states for illegal, unreported, and unregulated (IUU) fishing ${ }^{14}$ (which came into effect in 2016). ${ }^{15}$ 
Nonetheless, creating new standards or discerning new approaches through older treaties does not remove the overarching problems involving proper and effective governance and oversight over maritime issues, matters of standards' implementation and enforcement (see, e.g., Matz-Luck and Fuchs 2015: 499, 504), and integration of norms into domestic spheres (as well as integration and observance by other key actors, such as private economic actors). Further, it is worth recognizing and inculcating the changes to the shape and character of nation-states (the presumed key stakeholder and operator) that has occurred since the latter half of the previous century. For example, one might specifically observe the tensions that exist between the globalization of commerce (and the attendant power of the fishing industry) and the diminished capacities of the nationstate (see generally Roe 2013). The tertiary state-based rules are not geared for a globalized fishing industry. Ships can be composed of many nation members flying a different flag than the state in which it operates, employing people from around the world on one ship, and operating worldwide over areas that are not controlled by states (such as the High Seas, yet catching migrating species that enter into a state's EEZ and thus impact its catch limit). ${ }^{16}$ Coupled with state concessions for various ocean industries, and other state created tax incentives to entice and encourage investment and economic activity, the reliance on commerce as grounds for justifying actions that generate wealth at any cost (resulting in potentially viable, yet clearly short-term, goals) easily mute calls for upholding pre-established norms and standards, protecting overworked laborers, and respecting the marine environment. Additionally, states encourage the habit of creating flags of convenience (usually with very little oversight) (Warner 2015: 755), thereby further entrenching the ability to effectuate any form of maritime governance, with many times states complying with another state's rules simply as a matter of comity. There still are difficulties in maintaining port state control, and shipping companies continue to play the boundaries and flout rules relating to the environment to make it even more difficult for static states to 'govern' porous territorial agents.

How then might a viable maritime global governance structure be developed that includes relevant actors like Taiwan who maintain a large stake in fishing and other ocean industries while moving beyond the political squabbling and territorial-centric approach of states and attendant treaties? How might a governance structure further incorporate important and at times seminal actors outside of the formal state structure such as private economic entities, environmentally conscious organizations, and the scientific community, in a manner that also accounts for notions of sustainable economic development?

\section{Policy and Process}

One approach that can begin to address maritime governance would be to acknowledge the necessary integration between policy and process as grounds for creating a meaningful form of governance.

Policy may be understood as an attempt to create dynamic stabilities that are produced within a continuous flow of ongoing conduct (by the subjects whom one is trying to stabilize) (Roe 2013: 174). The desired end-role of policy is to allow for the emergence of a framework that provides a clear avenue for direction and management, while capturing the reality of diverse interests of the actors, and the massive, ongoing, changes to the environment and territory that is being governed.

Process on the other hand captures the continuous flow of conduct by recognizing 
the ongoing dynamic of inherent change, unstoppable time, and continuing dynamism of the subject involved. The maritime governance process is dealing with constant change to the area it is trying to 'govern' and the subjects involved (including marine life) are constantly shifting, it is clearly linked to time based events (including fishing as well as ongoing environmental change), and the forces involved are clearly experiencing rather dynamic and extreme changes. Thus, process is a causal factor that goes towards defining and shaping policy (Roe 2013: 175) and can assist with the creation of maritime global governance by capturing the fluidity to account for change, yet also the fixity that is needed to actually have a policy eventually emerge (Gertler 1988: 157).

An important factor then for encouraging an emergence of a dynamic policy as deriving from an actual process is recognizing the need for a clear (and desired) result through the creation of viable norms. For example, one may look to the Convention on International Trade in Endangered Species of Wild Fauna and Flora ${ }^{17}$ (CITES) as a good example of dynamic policy and continuously changing process combining to create a form of effective governance (Hanson 2007: 11). Key provisions of the CITES treaty (and other relevant global agreements) have become embedded in national decision-making standards and laws, and cooperation and differentiated responsibilities exist between different states pursuant to their economic status and capabilities. There also is a bevy of solid science and ongoing reporting documents that outline the immediate and long-term needs as well as measuring the different levels of success that are involved. Additionally, there exists important and on-going public awareness campaigns and continuous public concern over the subject of the treaty (preserving endangered species) that is heavily aided by media interest. These are further assisted by coordinated international efforts to address global problems involved with CITES such as compliance, preventing smuggling, novel ways to address corrupt behavior on the part of officials, regulating consumer behavior, and other factors going towards upholding the norms and entrenching the desired policy deriving from the CITES treaty. What resulted from the confluence of these factors in shaping the CITES process is more funding for capacity building within states that need it most to combat protect endangered species and even for the development of alternatives to undesirable activities (like poaching or corrupt governmental activity) (see, e.g., Roe, Nelson, and Sandbrook 2009). CITES has proven dynamic in that there are regular revisions to the basic agreements. Coupled with continued political cognizance and desire to tackle the problem at the global level by the UN, at the national level by states, as well as key involvement and awareness raising by non-governmental bodies (and even to some extent by industry) one witnesses the emergence of a viable governance model that is based on an ongoing and ever-shifting process yet rooted in policy that creates a form of stability.

Compared to maritime global governance (where alleviating important matters like the impacts of overfishing, dealing with predatory species, or protecting coral reefs, are paramount and immediate) the common characteristics for addressing these obstinate issues is that the control mechanisms lie largely in the hands of national and local governments. These static bodies are up against extremely powerful economic intermediaries who are subject to land-oriented norms that are rooted in sovereignty and jurisdiction for areas that are simply not suited for such contexts and are generally ineffective in addressing current environmental problems. Further, there is strong dissonance between relevant actors such as states and non-governmental organizations or between in- 
ternational agencies and states that might not always operate in tandem, consumer awareness, education, and involvement is sorely lacking, and scientific information is not utilized in a proper and effective manner or is too quickly dismissed.

\section{Socialization as an Inroad}

As noted above, governance is not just about creating a viable governing structure, but also entails incorporating a dynamic process to create a viable policy (Borzel and Risse 2010: 113). It is conceivable that a greater socialization of maritime governance to incorporate the variety of actors and influences such as those witnessed by the CITES framework (and to a certain extent is already happening in the maritime context) can lead towards a more effective and meaningful development and application of standards and protections. Thus, the mode of socialization when considering maritime global governance should incorporate not just spatial perceptions concerning who controls or governs a certain area (such as within an Exclusive Economic Zone), but also ongoing temporal applications as patterns shift, environments change, and various actors play out their roles.

Utilizing constructivist notions concerning the socialization of norms, as sometimes found within international human rights and international environmental law, can serve as an initial avenue for further explication. The socialization of norms involves the incorporation of a host of actors (beyond just the state) and creating an ongoing reference to, and reliance upon, norms by international organizations, non-governmental organizations, domestic actors, and other groups or individuals including private and economic actors. The goal is to eventually lead to a greater acceptance of such norms by the relevant targeted actors (such as a state as well as surrounding private actors who might have a role to play in adhering to such norms).

Importantly, when considering the key role of Taiwan in maritime governance matters, a socialization approach will inherently open the door for Taiwan participation, be it through the development of relevant cooperative management bodies that incorporate all states and entities affected by fishing policies (see, e.g., Mora et. al. 2016: 14), or as a result of potential initiatives proposed by Taiwan over areas it currently controls (see, e.g., McManus, Shao, and Lin 2010: 270).

While social constructivist scholars recognize the importance of international legitimacy between states as a form of influential currency, they also adopt an ideational approach that centers on the importance and use of a norm or emerging standard as grounds for fomenting change deriving from non-state actors as well. The focus lies on the role of non-state actors, such as nongovernmental actors or international organizations, in influencing states' and other actors' decisions to comply with norms ${ }^{18}$ in a variety of different ways. Because relations between various international and domestic actors are linked to institutional constructs (such as treaty based processes or international and regional organizations) the socialization approach emphasizes compliance-pull constructions like legitimacy given the inherent structural constraints embedded in the system that demand a state act in a certain manner. The turn to legitimacy, however, is coupled with emergent existing forces that result from ongoing discourse and norms that assist to shape the actions of states and other actors, such that a social constructivist approach provides the stages and processes through which norms become 'socialized' into domestic settings. Even in Taiwan, where accession to treaties proves problematic 
given the influence of Mainland China on world affairs, the state has adopted policies that reflect the norms and principles of the LOS, with a view towards integrating the rules into its domestic laws (Hu 2012: 195).

A relevant example that can also go a long way towards including Taiwan in maritime global governance is the Arctic Council (AC). The AC is principally composed of eight states, ten observer states, and six non-governmental organizations all of which take an active part in the AC's discussions and agreement drafting. The AC's binding Agreement on Enhancing International Arctic Scientific Cooperation from $2016^{19}$ resulted from ongoing meetings and various task forces composed of not only states, but also scientific experts and non-governmental organizations representing indigenous peoples in the region along with other interests. ${ }^{20}$

Of course, the compliance pull forces exist from within the state, such as from a domestic social movement or particular group making a claim, and from outside the state, such as transnational social networks or an international treaty body that pressure a state or other actor to act in accordance with the norm. By also allowing for the inculcation of a norm within a domestic context, changes within the governance structure can ensure that allow protections to take root in the state and its infrastructure (Risse and Sikkink 1999: 2). Socialization is especially useful in instances where no judicial challenge exists because the state might not have consented to international judicial oversight, the existing governance structure does not provide the means for judicial involvement, or a tribunal would simply be ineffective (or potentially even cause greater harm due to a state ignoring a decision). ${ }^{21}$ Yet, the norm can serve as part of the ongoing use of ideas and principles as challenges to, and part of the language of, actors making the claim for protection and by those with an actual interest in creating new forms of standards (be they economic actors or environmentalists). As different stages of socialization emerge, be it through legal changes, argumentation and persuasion, ongoing dialogue or strategic bargaining, ${ }^{22}$ reliance on the norm can take root and become more firmly entrenched in the state and society. Actors within a state are constantly shaping their identity and perceptions pursuant to internal and external forces, including other states, transnational actors, and domestic groups espousing ideals that are important to them.

Granted, governmental policies are not solely driven by domestic actors, but also by non-state transnational actors, like NGOs, international organizations, and treaty bodies who sway and influence the state. These actors can apply normative pressure on states through shaming and denunciation. Norms achieve stronger prescriptive status as they enter the discourse with the state, become further internalized in the legal system, and begin to guide state behavior as well. For example, the General Assembly's 2016 Resolution on Sustainable Fisheries ${ }^{23}$ can serve as groundwork for further engagement not just by states, but also by all relevant actors to refer and entrench the desired standards. It can serve as a form of benchmark and discursive framework for making claims and providing the contours to proper action, in a manner that includes non-state entities as well as states like Taiwan who play a major role in the issues to be regulated.

As the norm becomes part of the discourse, the discourse becomes a form of exchanging information, as well as a means of clarifying what form of protection is sought after. ${ }^{24}$ Actors will form their own collective understanding that is related to their identity as a means of sharpening their interests and desired scope of protection (Risse and Sikkink 1999: 14; Marsh and Payne 2007: 678). ${ }^{25}$ Relying on the norm internalizes the 
norm, validates reliance on the norm as part of accepted discourse, and leads to a form of institutionalization of the norm within the state (Risse and Sikkink 1999: 17; Goodman and Jinks 2004: 626), ${ }^{26}$ all of which open up avenues of protection. For example, the notion of corporate social responsibility as applied to fishing boats engaged in illegal, unreported, or unregulated (IUU) fishing would be better enforced if the desired standards are properly codified and entrenched in the enforcement mechanisms of the state. $^{27}$

The presumption is that the state will then have an internal social mobilization process whereby local actors and activists become more emboldened in relying on norms, and states would in turn become less inclined to deny the validity of norms (Risse and Sikkink 1999: 25-6). The state becomes engaged in a dialogical process that incorporates relevant norms as part of the legitimate and usual form of ongoing discourse (Risse and Sikkink 1999: 28; Marsh and Payne 2007). ${ }^{28}$ These norms can be mobilized to become a part of the legislative framework, allowing for a further form of internal institutionalized entrenchment (and possible challenges) to take place (Risse and Sikkink 1999: 29-30).

Socialization then recognizes the role of domestic and transnational actors to not only engage in political transformations through discourse and pressure, but also to alter internal domestic structures with a view towards stronger entrenchment of norms (Risse and Sikkink 1999: 4; Goodman and Jinks 2004: 626). ${ }^{29}$ Included in the various benefits of socialization of norms is the mobilization of domestic opposition to states not adhering to such standards, such as to incorporate the voices of NGO, social movements, and international organizations acting to uphold the emerging or applicable standards (Risse and Sikkink 1999: 5; Marsh and Payne 2007). ${ }^{30}$ Rather than get caught up in an interestoriented framework that might be centered on economics, military capacities, or other forms of power influence, socialization looks towards the ideas and existing communicative processes that tend to define the material and important factors and state interests at stake, and use this understanding to influence state preferences and political decisions (Risse and Sikkink 1999: 7; Marsh and Payne 2007). ${ }^{31}$ Taiwan would be presented with an opportunity to express its interests while also taking part in the development and application of emerging maritime global standards.

Undeniably, operating within the confines of the state to allow for entrenchment and enforcement of standards will not wholly address the aforementioned problems associated with maritime governance. This is particularly the case for maritime governance where the actors are also operating outside of formal state borders and states simply do not have the wherewithal to 'govern' all areas of the ocean.

Thus, securing states to adhere to standards is but one step towards creating viable policy that emanates from a dynamic process. Additional key factors include forms of voluntarism and soft law to develop effective norms that are more readily applicable and suited for maritime global governance. This too allows for participation opportunities by Taiwan to develop and apply proper governance standards by working not just with states, but also the surrounding actors who play a role in effective maritime global governance.

An example of how a set of governance norms might emerge is the FAO Port Agreement that went into effect in 2016. The agreement is interesting in that there remain serious jurisdictional issues concerning the scope and capacity of a port state to 
actually engage a vessel for illegal activity performed outside a state's area of control (such as on the High Seas) (see, e.g., Molenaar 2007: 225). ${ }^{32}$ Yet, the agreement stipulates that states may take measures beyond just denying right of port facilities ${ }^{33}$ to include as well standards that are required of regional fishing management organizations or other internal laws of the state (as long as they are in accordance with international law) (Kopela 2016: 100-101). ${ }^{34}$

Injecting a socialization approach to the agreement can provide further possibilities not only for a state say to criminalize IUU high seas fishing of endangered species (a possibility under the agreement and one envisioned when incorporating the FAO's desired norms), but also for the involvement of external actors who might be involved in monitoring the ships. Indeed, when discussing the potential for shaping and enforcing a code of conduct to protect the marine environment, involvement includes international conservation groups, intergovernmental bodies, non-governmental organizations, consumer groups, and civil society actors with a view towards engaging the public through educational initiatives, re-orienting consumer behavior and habits, and providing guidelines for practitioners and conservation groups (Bennett et. al. 2017: 415). Actions such as creating a certification scheme for IUU fishing sources or publishing rebukes (Ibid.) as well as establishing external reporting by non-state actors all assist the state to address potential jurisdictional issues and also allow for alternative means of enforcement by external actors that might be more effective than having a state authority arrest a fishing boat and its crew. Moving towards more ecologically oriented forms of territory, such as shared governance arrangement, would incorporate all interests involved as well as allow for a role of Taiwan in the policy shaping process (see, e.g., Lim and Liu 2017: 52; McGee, Gogarty, and Smith 2017: 88). Taiwan's involvement is especially necessary given its territorial possessions in the area like Itu Aba (Taiping) island, its active role in the fishing industry, and its stated desire to protect the environment. ${ }^{35}$

Importantly, the maritime governance process must incorporate a wider range of stakeholders to include media, politicians, interest-groups, and consumers while also carrying out international institutional reform at the level of sub-systems to allow for support systems for finance, economic development, and the environment all at the same time (in a manner similar to CITES). The links between these different actors operating in the sub-systems are essential to target and enhance as a means of building a shared vision that tends to earmark common problems and achieves common solutions (see, e.g., Benham 2017: 16). ${ }^{36}$ This is already witnessed by the work of the Arctic Group where the permanent participants (six indigenous peoples groups) work not only with the member and observer states, but also with the task forces and expert groups who are comprised of non-state representatives as well.

Further, diverse interactions amongst a variety of different actors will lead to the emergence of better normative instruments that tend to coalesce different interests (such as trade and the environment) to ameliorate the dire environmental issues that are only getting worse. Included herein would be the need for good scientific information, utilizing for example reliable organizations like the Intergovernmental Panel on Climate Change (IPCC) or Intergovernmental Oceanographic Commission (IOC) who are noted and respected bodies providing measured and apolitical data. Marine spatial planning could open the door for new approaches as to how space and the desired protected environment is perceived and regulated as it moves away from a state-oriented territorially 
based model (see, e.g., Matz-Luck and Fuchs 2015: 513-514; see also Roeben 2015: 36). ${ }^{37}$ Upon considering the importance of conservation for example, one can potentially achieve a new approach in delineating ocean spaces by adopting a non-tertiary oriented framework in a manner that alters the meaning of the 'freedom of the seas' and attendant fishing and navigation rights (Young 2016: 165; see also Manez et. al. 2014). ${ }^{38}$ Involving external parties also can be accomplished by using new and inexpensive technologies that can go a long way towards upholding governance and standards (such as tracking shipping movements through Google earth to address unreported fishing) as well as allow for a greater spread of technology systems to lesser-developed countries.

Granted it is important to realize that the socialization process is beset by what appears to be an over-deterministic (and possibly over-idealistic) argument, especially since one must also account for different and widely varied forms of reactions (by states and other key actors) (Shor 2008: 118; Marsh and Payne 2007: 668). ${ }^{39}$ The social environments of states radically differ (Goodman and Jinks 2004) ${ }^{40}$ and social norms tend to be a lot more diffuse and complex (Ibid.). ${ }^{41}$ Further, certain states desire over fishing or lenient shipping standards for example simply to feed their population, allow for ongoing employment of large sectors of the population, or as a means of bringing in more funds to the state coffers. Policies and reactions of states and relevant actors like the fishing industry, the indigenous population in the area, the shipping industry, local and foreign consumers, the variety of different civil society actors, and relevant international organizations might indicate and lead towards different conclusions and means for addressing problems (see, e.g., Bennett and Dearden 2014: 107). ${ }^{42}$

The socialization process is not discounting realist approaches that states and other actors affected by maritime global governance will inherently defer to their interests and fall back on their economic or security needs. Rather, the notion here is to acknowledge and incorporate the fact that diverse interests are involved; it is a matter of proper engagement and creating a viable framework that will allow for viable solutions. Transparency and accountability for example are essential for any governance program to be effective and acceptable to those who are affected, be they the fishing industry, local workers, or conservationists. Creating economic/private oriented incentives that are enticing to all the actors involved also would move forward forms of governance in a legitimate and fair manner (Bennett and Dearden 2014: 114) ${ }^{43}$ that can include conservation efforts as well. Indeed, a number of avenues exist for addressing the economic impact of conservation in a viable manner. Inclusion of relevant stakeholders like local economic actors (who might be most affected) and indigenous peoples (who maintain an important stake in any decision) in the decision making process is a first step. Compensating local users for opportunities forgone, and investing in community education and welfare to understand and be involved with potentially new-form opportunities (Jones et. al. 2013: 12), are but some of the avenues available for an economically viable and enduring framework. Indeed, investigations concerning local marine protected areas indicate that it can actually necessitate poverty alleviation, especially when program development that incorporates economic development with conservation is carried through past the implementation period (see, e.g., Gurney et. al. 2014: 98).

A solid governance structure also might start to place an emphasis on partnership models (such as public-private partnerships to engage broader audiences and account 
for all forms of interest). ${ }^{44}$ Linking up progressive, market-based, entities, civil society organizations (which can reflect a wide gamut of interests including environmental concerns along with the need for economic development) (Jones et.al. 2013: 12) ${ }^{45}$ and intergovernmental and other state-driven bodies is also an avenue for the emergence of viable policy. Consensus building and inclusive, participatory approaches with partnerships of diverse actors can result in clear and feasible objectives and a well-defined implementation authority. The importance of inclusivity is especially the case when supported with suitable knowledge and economic capacity development that are created and managed to incorporate changing situations and progress assessments. Such approaches also point towards the involvement of Taiwan in any form of maritime global governance. Taiwan's interests merit being accounted for upon recognizing, in a realistic manner, Taiwan's impact and role in economic and conservation decisions that are relevant not only to its immediate geographic area in the South China Seas, but also the ocean in general. ${ }^{46}$

Finally, it is important to point out that even with the advent of some forms of regional agreements regarding fishing management schemes (many of which include Taiwan simply by virtue of realistic necessity), a more integrated and effective structure is needed to address current maritime governance, rather than the existing patchwork systems (Warner 2015: 775). IUU and environmental changes are wreaking havoc with the fishing industry and extreme climatic events will only get worse as the ocean absorbs the majority of the climate alterations that are happening throughout the world.

\section{Conclusion}

In some ways, maritime governance has been happening for some time (albeit not necessarily on a global scale). For example, states are beginning to create marine protected areas as a means of conserving species and preventing overfishing. In certain instances, these forms of protection have even reflected a form of socialization as states have begun to incorporate appropriate norms into their domestic laws and have included relevant surrounding actors into the process. The means for protecting the Arctic for example includes not just states, but also indigenous peoples and other experts. There is a push towards inculcating norms as grounds for fomenting change, such as the FAO's recent move to have the Port State Agreement turn into binding international law (for signatory states).

What is missing however, and what seems to be sorely needed, is a form of maritime global governance that will effectively incorporate all relevant actors, create viable and enforceable norms that reflect a variety of interests, and allow for the emergence of applicable global management regimes that will adequately ensure for the protection of marine resources in a sustainable manner. To be effective, such a global framework should incorporate all relevant actors in the process who can play an important role in developing effective policy and lead to proper oversight and enforcement as well.

Despite Taiwan being an isolated state in many respects, it is a significant participant in maritime issues and can have a broad and lasting impact on policy development that can lead to effective maritime global governance. Taiwan possesses territory, is an important economic actor in the fishing industry, desires to act for and protect the environment, and is ready and able to incorporate the views of the wide gamut of relevant external actors, from environmental organizations to private economic firms. 
A socialization approach opens up the possibility to reconsider existing normative structures and think beyond the territorial based notion of state control, thus allowing for participation by states like Taiwan along with non-state actors who can assist in creating policy. Incorporating the interests of conservationists and the need for sustainability to provide for the ocean's survival will allow states to work with relevant civil society actors and globally engage maritime governance that properly prevents those with immediate, short-term, economic thinking who are acting at the expense of everyone else (and future ocean users as well). Thinking beyond territorial notions regarding the ocean allows for perceptions that measure environmental viability over economic opportunities, and encourages states to seek out alternative energy sources (like wind or solar power rather than fossil fuels) and more sustainable fishing methods (like aquaculture).

At the same time, economic concerns such as the need for development can be incorporated into decision-making processes that will capture the needs of those whose jobs have been displaced or have relied upon the ocean as a food source. Incorporative management and involvement of all relevant actors at the decision making and implementation process will allow for a movement away from focused and immediate economic needs as the defining factors of one's interests. Rather, local communities with the most at stake will not only better comprehend the process and reasoning behind the shifts (such as preventing overfishing), but will also become part of the process (such as to utilize the new areas for other purposes, like environmentally viable fish farms or eco-tourist areas, to name but a few of the possibilities). Taiwan can and should play a major role in these developments given its geographic position, economic and scientific capacities, and stated willingness to assist and be a responsible participant. A socialization shift then will move towards models that recognize the breadth of influential actors beyond the state who can and do play an important role in the ever-changing process that maritime governance involves, leading to the creation of viable and effective policy.

\section{NOTES}

${ }^{*}$ This paper resulted from funding provided by the Taiwan Fellowship Fund. In particular, many thanks to Professor Fu-Kuo Liu, Executive Director, Taiwan Center for Security Studies, Institute of International Relations, National Chengchi University, Taiwan (R.O.C.) for being such a gracious host.

${ }^{1}$ See discussion infra.

${ }^{2}$ See, e.g., Graczyk, Śmieszek, Koivurova, and Stępień 2016 (discussing the socialization of the Arctic Council's norms for both member states and observer states).

${ }^{3}$ See, e.g., Schwerdtner, et. al. 2014 noting for example the use of 'sasi laut' by Indonesia that placed temporal and spatial harvesting restrictions as a means of regulating marine resources.

For an overview of the issues surrounding maritime global governance, see Roe 2013.

${ }^{4}$ See, e.g., Charney and Prescott 2000: 463. The authors conclude that given the reality of Taiwan's status, it maintains the capacity to unilaterally declare independence.

${ }^{5}$ See http://www.fao.org/countryprofiles/en/ and http://www.fao.org/apfic/background/aboutasia-pacific-fishery-commission/en/.

${ }^{6}$ See chart at: https://www.google.com.tw/search?q=TAIWAN+TUNA+FISHING+IN+NUM BERS\&tbm $=$ isch\&tbo $=$ u\&source $=$ univ\&sa $=$ X\&ved $=0$ ahUKEwjJg8Gsgp_WAhVGFZQKHaPDCx4Q sAQITw\&biw $=1256 \&$ bih $=609 \#$ imgrc $=$ OZpx 2 xuyqGj6mM:

${ }^{7}$ https://www.ccsbt.org/. 
${ }^{8}$ https://www.npfc.int/about_npfc.

${ }^{9} \mathrm{https}: / /$ www.sprfmo.int/.

${ }^{10} \mathrm{https}: / /$ www.iattc.org/HomeENG.htm.

${ }^{11}$ Scanlon 2017: 35 (noting, at 36, that 'failing to incorporate Taiwan into the international high seas fishing regulation system would be problematic' given its significant presence in high seas fishing).

${ }^{12}$ Article 193 of the LOS.

${ }^{13}$ Articles 61(3) and 119(1) of the LOS.

${ }^{14}$ Agreement on Port State Measures to Prevent, Deter and Eliminate Illegal, Unreported and Unregulated Fishing_available at http://www.fao.org/documents/card/en/c/915655b8-e31c-479c-bf0730cba21ea4b0/ (hereinafter: FAO Port Agreement).

15 The Agreement went into effect in 2016. https://www.un.org/apps/news/story.asp? NewsID=54140\#.WZ7cDf frL8. See also discussion infra.

${ }^{16}$ A fishing boat might be used to merely send out different satellite boats to the high seas with all of them being subject to different flag states (or none at all) thus making it easier to evade domestic and international controls and oversight.

${ }^{17}$ Available at: https://cites.org/eng/disc/text.php.

${ }^{18}$ See, e.g., Greenhill 2010: 127 (noting at 129 how international governmental organizations better influence states' human rights practices through the socialization process as opposed to the traditional methods of punishment and coercion).

19 The document, from May, 11, 2017, is available at: https://oaarchive.arctic-council.org/ handle/11374/1916.

${ }^{20}$ Thus, the Russian co-chair of the Task Force for Enhancing Scientific Cooperation in the Arctic, Vladimir Barbin, noted that:

The uniqueness of the process of negotiating this document was that the permanent participants and the observers were given an opportunity to take part in preparing concrete provisions of this PanArctic intergovernmental document. This shows once again that all Arctic countries are committed to enhancing international cooperation in the Arctic and welcome the contributions from the other interested parties.

Arctic nations agree to more scientific cooperation, Radio Canada International, The Independent Barents Observer, July 14, 2016. Available at: https://thebarentsobserver.com/en/arctic/2016/07/arcticnations-agree-more-scientific-cooperation.

Note also the strong PRC interest in participating in Arctic governance, where the mainland sees an opportunity to effectively participate and shape global governance structures. See, e.g., Wu, F. 2016.

${ }^{21}$ Arguably that seems to be the case with the recent Philippines-PRC arbitral ruling from the LOS Tribunal of July, 2016 where the PRC stated at the outset that it will ignore the award, and even the Philippines has turned a blind eye to the award in its subsequent dealings with PRC. $C f$. Franckx 2017: 47 (concluding that the rise in the number of states using the LOS Tribunal mechanism over the past ten years also indicates an inclination towards better adherence to the decisions).

${ }^{22}$ See discussion infra.

${ }^{23} 2016$ General Assembly Resolution 71/123, December 7, 2016, available at: http://www.un. org/depts/los/general_assembly/general_assembly_resolutions.htm.

${ }^{24}$ Marsh and Payne 2007: 675 noting for example the emergence of the freedom of religion in different states and regions as a result of the right becoming part of the subjective understanding of culture (and asserting, at 680, that socialization requires both enculturation of norms as well as legal acceptance of same).

${ }^{25}$ Noting the importance of recognizing the different social and historical contexts in which religious freedom emerged, as but one avenue for addressing the matter of relativism in human rights. 
${ }^{26}$ Highlighting the distinctiveness of the acculturation process - as opposed to coercion and persuasion - as the former allows for states to adopt the perceptions and patterns of surrounding cultures.

${ }^{27}$ Granted, a stable underlying infrastructure is needed as well that includes more participants like the media, consumers, and non-governmental organizations. See discussion infra for further elaboration on the importance of these participants in creating effective global maritime governance.

${ }^{28}$ Referring to this as a form of strategic bargaining.

${ }^{29}$ Referring to this stage as the acculturation of rights.

${ }^{30}$ Noting the capacity to raise the 'moral' consciousness of states and engage in argumentation and persuasion is largely driven by domestic actors within a state.

${ }^{31}$ Noting that this is a form of institutionalization and habitualization of state behavior.

${ }^{32}$ Noting how a port state might make use of its duties towards the international community as one of the means by which to move from a voluntary-based structure to a more mandatory framework.

${ }^{33}$ FAO Port Agreement Article 4(1)(b).

${ }^{34}$ Noting the emergence of state practice indicating a willingness to act against IUU activity on the high seas and noting further at 108-109 the potential for a universal jurisdiction based on the global commons, to protect the environment.

${ }^{35}$ See The Ministry of Foreign Affairs, Republic of China (Taiwan)'s official statement on the South China Seas, entitled: Sustainable Governance and Enduring Peace in the South China Sea available at: http://www.mofa.gov.tw/en/theme.aspx?n=E5A0D5E2432C234D\&s=83376F561B7165E6\& sms $=$ BCDE19B435833080.

${ }^{36}$ Discussing the importance of including local communities at the initiation stages of environmental impact assessments rather than ex post facto, when environmental damage is already done.

${ }^{37}$ Proposing the use of negotiated settlements as a means of addressing territorial disputes such as those found in the South China Seas.

${ }^{38}$ Discussing the importance of historical studies of the marine ecosystem to provide context and better insight into ecosystem changes.

${ }^{39}$ Noting the overly linear and teleological bent of the socialization argument.

${ }^{40}$ Noting the need to account for different social environments of states when considering the coercive approach to create change.

${ }^{41}$ Noting the weakness of the persuasive approach when considering the variety of diffuse social norms.

${ }^{42}$ The authors found that rural fishing communities in Thailand located near marine protected areas maintain a negative view of such areas because they are understood to affect their livelihood.

${ }^{43}$ Note the importance of creating alternative forms of livelihood, connecting those affected economically with available assets, and having them share in the benefits offered by conservation efforts as new industries emerge. See also Jones, Qiu, and De Santo, 2013: 12 (noting the importance of equity and fairness in resource distribution as one of the key grounds for viable marine governance).

${ }^{44}$ Bennett and Dearden, 2014: 114 (noting the benefits of involving local people in management decisions and long-term development plans); Mellado, et. al. 2014: 390 (importance of local ecological knowledge given impact on effective management of marine protected areas).

${ }^{45}$ Noting for example the importance of using non-governmental organizations as an avenue for implementing incentives and proper management in marine protected areas.

${ }^{46}$ Taiwan maintains one of the largest distant water fishing industries (in terms of scale), see 2015 ROC Fisheries Agency Report, available at: http:/www.fa.gov.tw/en/FisheriesoROC/con tent.aspx?id=2\&chk=05d9ffd2-651d-4686-a2d1-a44413152366\&param=pn\%3D1 and it is subject to much stress to maintain existing fishing levels, see e.g. Murphy 2015. 


\section{REFERENCES}

Benham, C. 2017. Aligning Public Participation with Local Environmental Knowledge in Complex Marine Social-Ecological Systems. Marine Policy 82: 16-24.

Bennett, N. et. al. 2017. An Appeal for a Code of Conduct for Marine Conservation. Marine Policy 81: 411-418.

Bennett, N., and Dearden, P. 2014. Why Local People do not Support Conservation: Community Perceptions of Marine Protected Area Livelihood Impacts, Governance and Management in Thailand. Marine Policy 44: 107-116.

Bernstein, S. 2011. Legitimacy in Intergovernmental and Non-state Global Governance. Review of International Political Economy 18: 17-51.

Borzel, T., and Risse, T. 2010. Governance without a State: Can it Work? Regulation and Governance 4: 113-134.

Charney, J., and Prescott, J. 2000. Resolving Cross-Strait Relations between China and Taiwan. American Journal of International Law 94: 453-477.

Chintoan-Uta, M., and Silva, J. R. 2017. Global Maritime Domain Awareness: A Sustainable Development Perspective. WMU Journal of Maritime Affairs 16: 37-52.

Ecclestone, R. 2013. The Dynamics of Global Economic Governance.UK: Elgar Publishing.

Franckx, E. 2017. The Effects of the South China Sea Dispute and the Arbitral Ruling on UNCLOS and International Law. In Hiebert, M., Poling, G., and Cronin, C. (eds.), In the Wake of Arbitration (p. 47). Washington, DC: Rowman \& Littlefield.

Goodman, R., and Jinks, D. 2004. How to Influence States: Socialization and International Human Rights Law. Duke Law Journal 54: 621-703.

Graczyk, P., Śmieszek, M., Koivurova, T., and Stępień, A. 2016. Preparing for the Global Rush: The Arctic Council, Institutional Norms, and Socialization of Observer Behaviour. In Keil, K., and Knecht, S. (eds.), Governing Arctic Change: Global Perspectives (p. 121-139). London: Palgrave Macmillan.

Greenhill, B. 2010. The Company You Keep: International Socialization and the Diffusion of Human Rights Norms. International Studies Quarterly 54: 127-145.

Gurney, G. et. al. 2014. Poverty and Protected Areas: An Evaluation of a Marine Integrated Conservation and Development Project in Indonesia. Global Environmental Change 26: 98-107.

Hanson, A. 2007. Global Governance for Environment and Sustainable Development. Canada: Institute for Sustainable Development. URL: https://www.iisd.org/pdf/2007/ igsd_global_gov.pdf.

Hu, N. 2012. Taiwan's Oceans Policymaking: Its Development and Assessment. Coastal Management 40: 195-208.

Jones, P. Qiu, W. and De Santo, E. 2013. Governing Marine Protected Areas: SocialEcological Resilience through Institutional Diversity. Marine Policy 41: 5-13.

Karim, M. S. 2015. Prevention of the Pollution of the Marine Environment from Vessels: The Potential and Limits of the International Maritime Organisation. Switzerland: Springer Intl.

Kopela, S. 2016. Port State Jurisdiction, Extraterritoriality, and the Protection of Global Commons. Ocean Development and International Law 47: 89-130. 
Lim, M., and Liu, N. 2017. Condominium Arrangements as a Legal Mechanism for the Conservation of the South China Sea Large Marine Ecosystem. Asia-Pacific Journal of Ocean Law and Policy 2: 52-87.

Manez, K. et. al. 2014. The Future of the Oceans Past: Towards a Global Marine Historical Research Initiative. PLOS ONE 9. URL: http://journals.plos.org/plosone/article?id= 10.1371/journal.pone.0101466\#s4.

Marsh, C., and Payne, D. 2007. The Globalization of Human Rights and the Socialization of Human Rights Norms. Brigham Young University L.aw Review 2007: 665-687.

Matz-Luck, N., and Fuchs, J. 2015. Marine Living Resources. In Rothwell, D., Elferink, A., Scott, K., and Stephens, T. (eds.), The Oxford Handbook of the Law of the Sea p. 491). Oxford: Oxford University Press.

McGee, J., Gogarty, B., and Smith, D. 2017. Associational Balance of Power and the Possibilities for International Law in the South China Sea. Asia-Pacific Journal of Ocean Law and Policy 2: 88-116.

McManus, J., Shao, K., and Lin, S. 2010. Toward Establishing a Spratly Islands International Marine Peace Park: Ecological Importance and Supportive Collaborative Activities with an Emphasis on the Role of Taiwan. Ocean Development and International Law 41: $270-280$.

Mellado, T. et. al. 2014. Use of Local Knowledge in Marine Protected Area Management. Marine Policy 44: 390-396.

Molenaar, E. 2007. Port State Jurisdiction: Toward Comprehensive, Mandatory and Global Coverage. Ocean Development and International Law 38: 225-257.

Mora, C. et. al. 2016. Dredging in the Spratly Islands: Gaining Land but Losing Reefs. PLoS Biol 14. URL:10.1371/journal.pbio.1002422.

Murphy, S. 2015. EU Gives Yellow Card to Taiwan. Seafood Source October 1, 2015. URL: https://www.seafoodsource.com/news/environment-sustainability/eu-gives-yellow-cardto-taiwan.

Picciotto, S. 2006. The Retreat of the State: Challenges to Law and Lawyers. Regulatory Networks and Global Governance. UK: Institute of Advanced Legal Studies, University of London.

Risse, T., and Sikkink, K. 1999. The socialization of International Human Rights Norms into Domestic Practices: Introduction. In Risse, T., Ropp, S., and Sikkink, K. (eds.), The Power of Human Rights: International Norms and Domestic Change (pp. 1-39). Cambridge: Cambridge University Press.

Roe, D., Nelson, F., and Sandbrook C. 2009. Community Management of Natural Resources in Africa: Impacts, Experiences and Future Directions. UK: International Institute for Environment and Development.

Roe, M. 2013. Maritime Governance and Policy Making. London: Springer-Verlag.

Roe, M. 2013. Maritime Governance and Policy-Making: The Need for Process Rather than Form. The Asian Journal of Shipping and Logistics 29: 167-186.

Roeben, V. 2015. The Equitable Distribution of Marine Resources by Agreement of States The Case of the South China Sea. Chinese Journal of Global Governance 1: 36-66. 
Scanlon, Z. 2017. Incorporating Taiwan in International Fisheries Management: The Southern Indian Ocean Fisheries Agreement Experience. Ocean Development and International Law 48: 35-51.

Schatz, V. 2016. Fishing for Interpretation: The ITLOS Advisory Opinion on Flag State Responsibility for Illegal Fishing in the EEZ. Ocean Development and International Law 47: 327-345.

Schwerdtner, M. et. al. 2014. The Future of the Oceans Past: Towards a Global Marine Historical Research Initiative. PLOS One, July 2. URL: https://doi.org/10.1371/journal. pone.0101466.

Selkou, E., and Roe, M. 2004. Globalisation, Policy and Shipping. Fordism, Post-Fordism and the European Union Maritime Sector. Cheltenham: Edward Elgar.

Shahid, A., and Yerbury, H. 2014. A Case Study of the Socialization of Human Rights Language and Norms in Maldives: Process, Impact and Challenges. Journal of Human Rights Practice 6: 281-305.

Shor, E. 2008. Conflict, Terrorism, and the Socialization of Human Rights Norms: The Spiral Model Revisited Social Problems. Social Problems 55: 117-138.

Stephens, T. 2015. Warming Water and Soaring Seas: Climate Change and Ocean Acidification. In Rothwell, D., Elferink, A., Scott, K., and Stephens, T. (eds.), The Oxford Handbook of the Law of the Sea (p. 777). Oxford: Oxford University Press.

Warner, R. 2015. Conserving Marine Biodiversity in Areas beyond National Jurisdiction: Co-Evolution and Interaction with the Law of the Sea. In Rothwell, D., Elferink, A., Scott, K., and Stephens, T. (eds.), The Oxford Handbook of the Law of the Sea (p. 752). Oxford: Oxford University Press.

Wu, F. 2016. China's Ascent in Global Governance and the Arctic. Vestnik $S P b G U$, Series 6 [Вестник СПбГУ Сеp. 6]. URL: https://cyberleninka.ru/article/v/china-s-ascent-inglobal-governance-and-the-arctic.

Young, M. 2016. Then and Now: Reappraising Freedom of the Seas in Modern Law of the Sea. Ocean Development and International Law 47: 165-185. 